\title{
4-4-4ＨS ディスクドライブ
}

\section{三澤 誠 一十}

\section{1. ま え がき}

本稿では, 新世代の光磁気ディスクドライブとし て,ソニー株式会社，株式会社日立製作所扔よび米国 $3 \mathrm{M}$ 社の 3 社で共同提案した HS フォーマットの特徵 と，それに導入された新技術の概略などを紹介する。

\section{2. 開発の背景}

近年, コンピュータを取り巻く環境は次のように著 しく変化している.

・マイクロプロセッサの処理能力の向上に伴う OS の肥大化やアプリケーションソフトの大型化

・音声や画像などの大容量デー夕の取り込み

・インターネットの普及に伴う大容量データの氾濫

その結果, 記録媒体が取り外せるデータストレージ に対する高速化, 大容量化抒よび低価格化の要求が高 まってきている.

HS ディスクドライブ(写真 1) は, 従来の光磁気記 録の弱点を克服し, 光磁気記録が持つ高信頼性を維持 したまま, 高速化と大容量化とを追及した新世代の光 磁気ディスクドライブとして開発された。

\section{HS フォーマットの特徵}

HS ドライブとディスクの主な仕様を表 1 に示す.

\section{$3.188 \mathrm{~mm}$ (3.5 型)で $650 \mathrm{MB}$ の大容量}

HS フォーマットでは, 後述する「レーザストロー ブ磁界変調記録方式」を採用することにより, 最短ビ ット長 $0.41 \mu \mathrm{m} / \mathrm{b}$ （面記録密度換算では, $1.3 \mathrm{~Gb} /$ $\left.\mathrm{in}^{2}\right)$ の高記録密度を達成した。この面記録密度は, 磁気記録方式も含めて, 現時点で商品化された記録方 式の中では世界最高の水準である.

\section{2 ダイレクトオーバライト機能による高速書込み}

従来の光磁気記録では, 記録したいセクタをまず消 去し, ディスクが 1 回転した後で当該セク夕にデー夕 を書込んでいる，そのために書込みに要する時間がか

†ソニー株式会社 コンピュータペリフェラル\&コンポーネン トカンパニーHS 事業室

“4-4-4 Hyper Storage Disk Drive” by Seiichi Misawa (HS Business Department, Computer Peripherals \& Components Company, Sony Corporation, Atsugi)

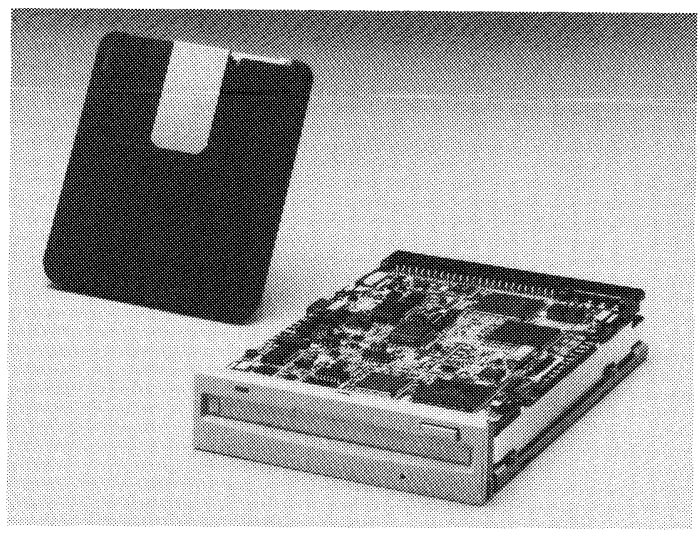

写真 1 HS ドライブとディスク

かり, 光磁気ディスクドライブの応用もデータのバッ クアップやデータの交換用途などに限られていた．

HS フォーマットでは, 後述する「レーザストロー ブ磁界変調記録方式」を採用することにより，事前の 消去が不要なダイレクトオーバライト機能を実現し, ハードディスクドライブに迫る高速書込みを実現し た。

\subsection{ROM およびパーシャル ROM のサポート}

HS フォーマットでは, サンプルサーボ方式を採用 することにより, 読出し専用の ROM ディスクや読出 し専用領域と読み書き領域を 1 枚のディスクに共存さ せたパーシャル ROM ディスクの製造を容易にしてい る。

\section{4. 導入された新技術}

\section{1 レーザストローブ磁界変調記録方式 ${ }^{11}$}

この記録方式は, 記録データで変調した磁界にパル ス発光レーザを同期させる記録方式である。記録され たピットエッジは, 磁界反転の過渡特性によらず, レ ーザパルスの照射タイミングのみによって決定される ため, 線方向の記録密度を大幅に向上させることがで きた。

\section{2 サンプルサーボ方式 ${ }^{11}$}

この方式では, 従来の連続溝サーボ方式で使われて いるディスク上のガイドグルーブが不要になることに 


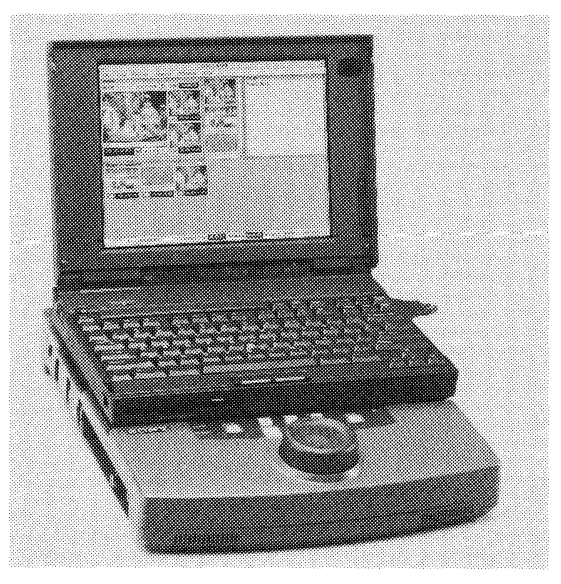

写真 2 ポータブルノンリニア編集機

より，高トラック密度化が容易になった。また， 1 ビ ームでトラッキングとデータの読み書きが可能になつ たことにより, 光学系のコストダウンもできた.

\section{3 薄板ディスク ${ }^{11}$}

高記録密度化のために, 短波長レーザ $(685 \mathrm{~nm})$ と 高 NA(0.55)の光学系を使用するとディスクのスキュ ーマージンが狭くなる. HS フォーマットでは, 0.8 $\mathrm{mm}$ 厚のディスク基板を用いることにより, この問題 を解決した。

\subsection{1 軸アクチュエータ}

光ピックアップ部の小型化抢よび高速化を図るため に, 可動部総重量が $8 \mathrm{~g}$ 以下の 1 軸アクチュエータを 新規に開発した。

\section{5 防塺構造}

機構部は，セミハーメチック構造を採用し，ゴミな どの混入の少ない高信頼性構造を実現した。

\section{5. アプリケーション}

HS ディスクドライブは, コンピュータ周辺機器の みならず, 業務用 $\mathrm{AV}$ 機器にも使用できる信頼性と 耐久性をも具備している。

写真 2 は, HS ディスクドライブを搭載したポータ ブルノンリニア編集機である。この応用例では，1枚 のディスクに約 40 分の取材された映像/音声データが 記録でき, 取材現場での EDL(Edit Decision List) 作 成を可能にしている.

これ以外に HS ディスクドライブは, ラジオ局向け オーディオ録再機にも採用されている.

\section{6. 今後の展開}

HS フォーマットは, $650 \mathrm{MB}$ から始まり， 2 倍密 $1710(70)$
表 1 HS ドライブ/ディスクの主な仕様

\begin{tabular}{l|l}
\hline \hline ディスク & 片面 (カートリッジ入) \\
\hline ディスク径 & $88 \mathrm{~mm}$ \\
\hline ディスク厚 & $0.8 \mathrm{~mm}$ \\
\hline トラックピッチ & $1.2 \mu \mathrm{m}(21.2 \mathrm{kTPI})$ \\
\hline 記録密度 & $0.41 \mu \mathrm{m}(60.5 \mathrm{kBPI})$ \\
\hline カートリッジ外形寸法 & $92(\mathrm{~W}) \times 97(\mathrm{~L}) \times 5(\mathrm{H}) \mathrm{mm}$ \\
\hline 容量 & $650 \mathrm{MB}$ \\
\hline セクタ長 & $2,048 \mathrm{~B}$ \\
\hline レーザ波長 & $685 \mathrm{~nm}$ 赤色レーザ \\
\hline 対物レンズの NA & 0.55 \\
\hline サーボ方式 & サンプルサーボ \\
\hline 変調方式 & $\mathrm{NRZI}$ \\
\hline データ検出方法 & パーシャルレスポンス, ビタビ復号 \\
\hline 回転数 & $2,400 \mathrm{rpm}, \mathrm{ZCAV}$ \\
\hline データ転送速度 & $2($ 外周 $) \sim 1($ 内周 $) \mathrm{MB} / \mathrm{s}$ \\
\hline 記録方式 & レーザストローブ磁界変調方式 \\
\hline 平均シーク時間 & $33 \mathrm{~ms}$ 以下 \\
\hline ドライブ外形寸法 & $101.6(\mathrm{~W}) \times 25.4(\mathrm{H}) \times 146(\mathrm{D}) \mathrm{mm}$ \\
\hline ホストインタフェース & FastSCSI \\
\hline
\end{tabular}

度 $(1.3 \mathrm{~GB}), 4$ 倍密度 $(2.5 \mathrm{~GB})$ 一と容易に拡張でき るように設計されている。

$650 \mathrm{MB}$ の HS フォーマットは, 1996 年 6 月に開催 されたECMA 総会において, ECMA-239として規 格登録が承認された。同時に本規格は, ECMA 登録 後, ファーストトラック制度によって ECMA から ISO 一国際標準化提案がなされることも合わせて承認 された。なお，2 倍密度の HS フォーマットは，1996 年 6 月現在, ECMA/TC 31 (光ディスクの標準化審 議に関するテクニカル・コミティー) で審議が行われ ている。

(1996 年 7 月 15 日受付)

\section{〔参 考 文 献〕}

1) Shigeru Yokono, Toru Takeda, Tetsu Watanabe and Minoru Tobita: "MPEG2 Data Rate Recordable 3.5Inch Optical Disk", IEEE Trans. Consum. Electron., 41, 3, pp. 516-520 (Aug. 1995)

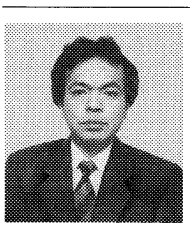

多澤 誠一 1987 年, ソニー(株)に入社. 以来, 情報処理研究所, 総合研究所, 情報通 信研究所を経て, 1994 年より, HS ゙ィイク ドライブ事業に従事. 